\title{
制御性を考慮したエレベータかご構造設計によるアクティブ制振技術*
}

\author{
野口 直昭*1, 荒川 淳*1, 三好 寛 ${ }^{* 2}$
} 河村 陽右 ${ }^{* 3}$ ，吉村 卓也 ${ }^{* 4}$

\section{Active Vibration Control Technology for Elevator Cars Considering Controllability}

\author{
Naoaki NOGUCHI ${ }^{*}$, Atsushi ARAKAWA, Kan MIYOSHI \\ Yosuke KAWAMURA and Takuya YOSHIMURA \\ ${ }^{* 1}$ Hitachi Research Laboratory, Hitachi, Ltd. \\ Horiguchi 832-2, Hitachinaka-shi, Ibaraki, 312-0034 Japan
}

Several active suspension systems have been developed to improve the ride quality of high speed elevators. However, none of these systems consider suppressing multi modal vibrations when a car moves over the bumps of a guide rail. We propose a structural design of the car that considers controllability and maintains a high performance while reducing vibrations with minimum actuators. The stiffness of the roller guides is designed to minimize the difference of the two phases corresponding to translational and rotational modes: specifically, the lower guide should be twice as stiff as the upper one. Experimental results showed that the proposed system can suppress vibration much more effectively compared to the conventional method using the closed-loop transfer function. The results of time response analysis and experiments also showed that the proposed structure enables a much higher control performance than the conventional one.

Key Words : Elevator, Active Control, In-Phase, Modal Analysis

\section{1. 緒言}

自動車・鉄道などの乗り心地の改善を目的として，アクティブやセミアクティブサスペンションの研究が広く 行なわれ，実用化が進んでいる，自動車の先行研究では，主に単輪のタイヤとばねからなるサスペンションにつ いて，スカイフックダンパ理論に基づいた制御設計 ${ }^{(1)}$ が代表的である. さらに $\mathrm{H} \infty$ 制御理論を適用したアクティ ブサスペンションの 4 輪モデル適用による性能向上方法も実車での検証が行なわれる他 ${ }^{(2)}$, 前後輪の時間差タイ ヤ横力変化特性を考慮したアクティブサスペンションの設計手法 ${ }^{(3)}$ が提案されている. エレベータは, 自動車の 路面に相当するガイドレール上を乗りかごが走行するシステムで，上下に設置したガイドローラがレールの不整 を受け，乗りかごに振動が伝播する。これに対して，著者らは既にガイド装置にアクチュエータを搭載したアク ティブガイド装置の機構と制御方法を開発した ${ }^{(4)}$ 。この研究では，主に実稼働中の振動モードを把握し，乗りか ごの制御設計モデルとして，低次元の剛体モデルを提案している．また，アクチュエータの設置位置は，上側よ りも下側のガイド装置から床への振動伝達率が高いことから，乗りかご下側のみに設置した．しかし，並進と回 転を含んだ多モード制振の制御性やアクチュエータやセンサの配置については，十分考慮されていない．多モー ドの制振については，ハードディスクの位置決めヘッドにおいて，摇動軸受のばねと摇動アームからなる振動系 の固有モードを剛体モードと同相化設計して制御帯域をより高く設定する研究事例がある(5) (7)。これは，ボイス

\footnotetext{
${ }^{*}$ 原稿受付 2012 年 5 月 27 日

${ }^{* 1}$ 正員，(株) 日立製作所 日立研究所（†312-0034＼cjkstart茨城県ひたちなか市堀口 832-2）

*2 正員，（株）日立製作所 都市開発システム社 水戸事業所 設計開発本部（テ312-8506 茨城県ひたちなか市市毛 1070）

*3 (株) 日立製作所 都市開発システム社 水戸事業所 設計開発本部

${ }^{* 4}$ 正員, フェロー, 首都大学東京 大学院 理工学研究科（广192-0397 東京都八王子市南大沢 1-1）

E-mail: naoaki.noguchi.hu@hitachi.com
} 
コイルモータによる制御入力と, ヘッド部の観測点の 1 入力 1 出力系(SISO 系)の位置決め制御系を対象としてお り, エレベータのように多入力制御(MIMO 系)では, 制御設計が困難となる. 本研究では, 乗りかごのローラガ イド装置の上下の剛性配分などを変更して, 励起される複数のモードの位相を最小化して制振効果を高める構造 と，その多モードの制振設計方法について述べ，解析と走行等価試験によりその有用性を検証する.

\section{2. 乗りかごの振動特性と構造設計}

\section{$2 \cdot 1$ エレベータの構造と振動モード}

一般的な高速エレベータの概略を図 1 に示寸. 乗りかごは左右に配置されたガイドレールの上を, 図 2 に示寸ゴム製の口 一ラが回転しながら走行する. 乗客が乗りこむ”かごは，かご室とかご枠フレームからなり，かご室は防振ゴムを介して， 防振支持されている. エレベータの横方向の乗り心地を評価する場合には，一般的に ISO で規定されたフィルタを用いて いる( ${ }^{(8)}$.このため, 本研究では乗り心地一の影響が大きい $4[\mathrm{~Hz}]$ 以下を対象とする. かごの振動は, 高速化が進むと，ガイ ドレールの据付時に発生する不整により, 横振動が湿著になる傾向がある.

エレベータは上昇下降中に，レールの不整による強制変位やロープの振動などを受けながら３次元の挙動を示し，並進， ピッチング，ローリング等の低次の振動モードが存在する. 4 [Hz]以下に限定すると，かご室とかご棵は一体に運動し， 1 つの剛体として考えることができる(9). 図3に, FDD (Frequency Domain Decomposition)を用いた実稼働モート解析の結果を 示寸. これは, レールのX方向のみに人工的に不整を与えた場合に励起された $4[\mathrm{~Hz}]$ 以下の 1 3 次モードのモードベクト ルを示している. 本図では, 乗りかごの運動方向を図 1 の左上図に従い，X方向の並進運動を TX，以下Y方向，Z方向の 並進運動を TY，TZ と定義する. また， $\mathrm{X}$ 軸周り，Y 軸周り， Z 軸周りの回転運動を $\mathrm{RX}, \mathrm{RY}, \mathrm{RZ}$ と定義する. TX, RZ，

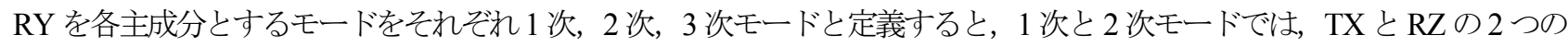
方向が連成し，TY，TZ，RX，RY 方向とは連成度が小さいことがわかる. また，3 次モードについては，RY 方向が主で その他の方向とは連成しにくい，これは，図4に示すように乗りかごの X方向の重心位置が，左右のレールを結ぶ線上に あって, X方向のレール不整でY方向には運動しにくいという構造的な特徵によるものである. また, Y 方向については, 同様の手順により TX と RX モードが抽出されると考えられるが，以下の解析検討では $\mathrm{Y}$ 方向よりも自由度の多いX方向 を主に検討することにする.

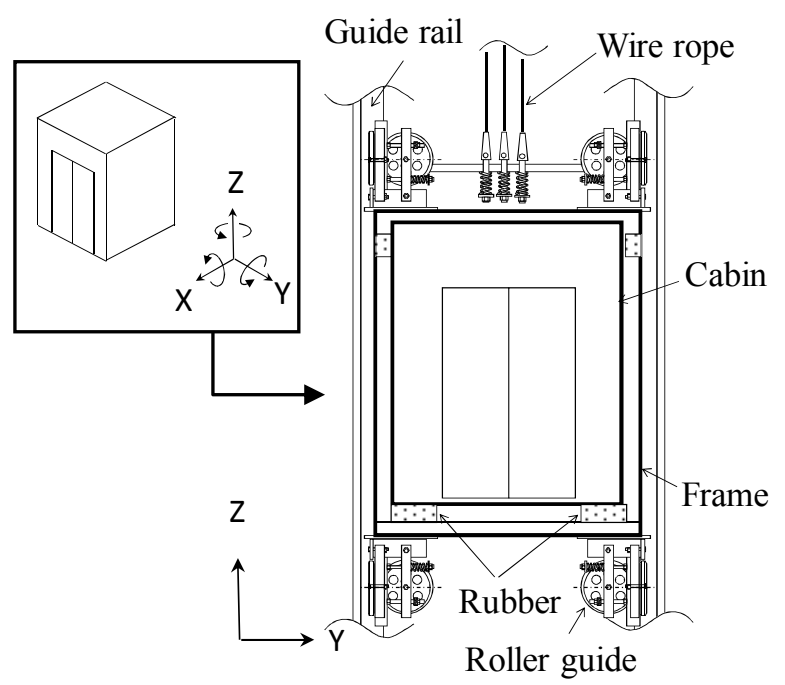

Fig. 1 Overview of elevator

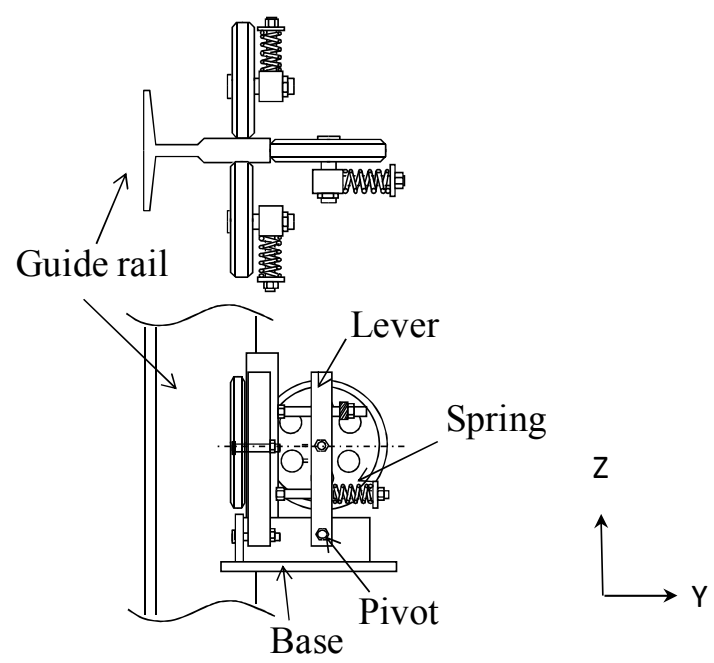

Fig. 2 Dynamic model 


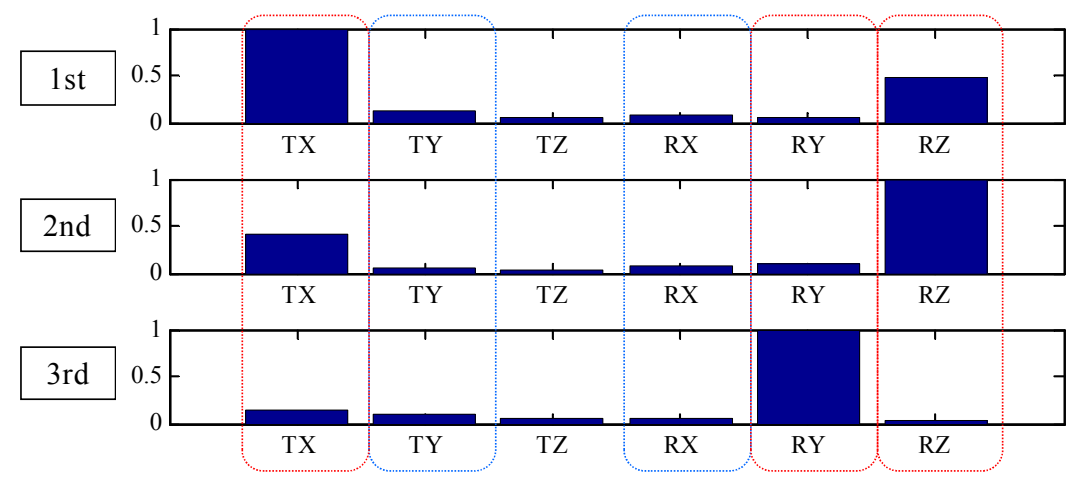

Fig. 3 Mode shape in operation

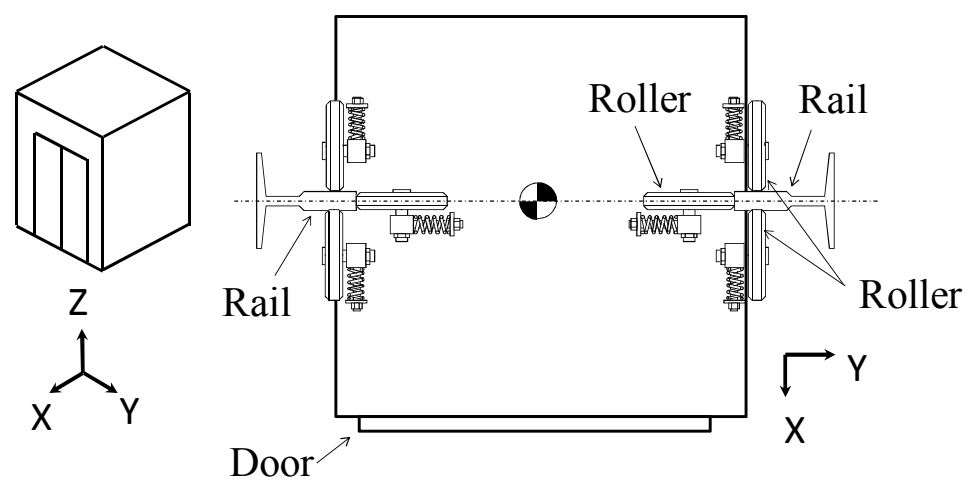

Fig. 4 Upper view of elevator car (XY Plane)

\section{$2 \cdot 2$ かごの解析モデル}

レール曲がりに起因するX方向とY 方向の振動を検討するにあたって, 先に述べたこれらの非連成の特性を利用して TX と RY と RZの振動解析用モデルと，TY と RX の振動解析用のモデルの 2 つ分離した. 前者の X 方向に関する力学モデ ルを図 5 に示寸. かご室とかご枠フレームは，1つの剛体としてモデル化しだ．ローラガイド装置は，かごの上下 4 か所 に設置されており，図2 に示すようにローラをレバーにブッシュを介して回転自由に固定し，このレバーはかごと回転自由 に接続されている. このローラガイド装置は, 本モデルでは等価な質量を有する質点およびローラとローラの押付ばねを線 形ばねと線形ダンパとしてモデル化した．なお，後者の押付ばねはローラの中心位置の等価岡性，等価減衰とした。ここ では, X方向のローラの岡性を $k_{\ell r u}, k_{r r u}, k_{\ell r d}, k_{r r d}$ とし, 押付ばねの等価岡性を $k_{\ell g u}, k_{r g u}, k_{\ell g d}, k_{r g d}$ で表わす. レールはかご の左右にあり $x_{0 u \ell}, x_{0 d \ell}, x_{0 u r}, x_{0 d r}$ の合計 4 か所からローラガイド装置を介してかごへの強制変位が作用寸る.

このモデルの運動方程式は以下で表わされる.

$$
[\mathbf{M}]\{\ddot{\mathbf{q}}\}+[\mathbf{C}]\{\dot{\mathbf{q}}\}+[\mathbf{K}]\{\mathbf{q}\}=\{\mathbf{f}\}
$$

ここで，qは状態量，M，C，Kははそれぞれ質量，減衰，岡性マトリクスを表すレールの強制変位による外力ベクトルは 以下で与えられる.

$$
\mathbf{f}=\left[\mathbf{K}_{\mathbf{F}}\right]\left\{\mathbf{X}_{0}\right\}+\left[\mathbf{C}_{\mathbf{F}}\right]\left\{\dot{\mathbf{X}}_{0}\right\}
$$

ここで， $\mathrm{K}_{\mathrm{F}}, \mathrm{C}_{\mathrm{F}}$ はそれぞれガイド装置の岡性マトリクス，減衰マトリクスを表す．状態ベクトルは 

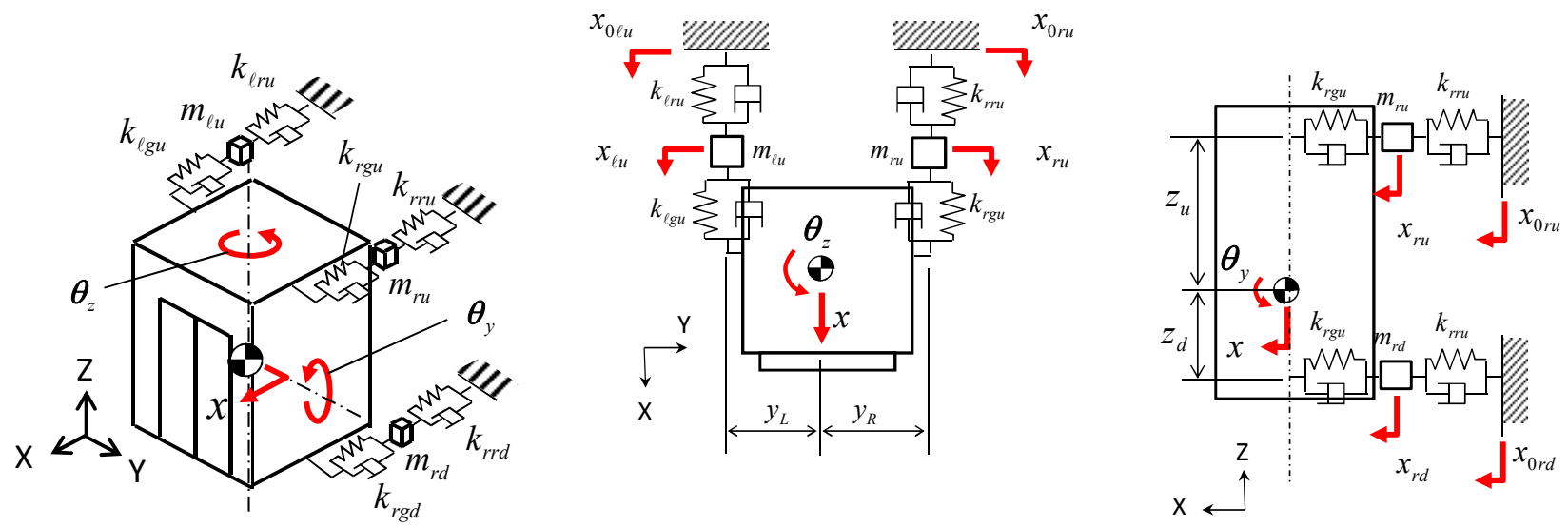

Fig. 5 Dynamic model for elevator car (for TX, RY, and RZ motion)

$\{\mathbf{q}\}=\left\{\begin{array}{lllllll}x & \theta_{y} & \theta_{z} & x_{r u} & x_{r d} & x_{\ell u} & x_{\ell d}\end{array}\right\}^{T}$, 強制外乱を表す行列は $\left\{\mathbf{X}_{0}\right\}=\left\{\begin{array}{llll}x_{0 \ell u} & x_{0 r u} & x_{0 \ell d} & x_{0 r d}\end{array}\right\}^{T}$ である. それぞ れのラプラス変換を大文字で表わせば, 左上側のガイド装置が受ける強制変位から床左前方変位に対する伝達関数は(3)式 となる。

$$
G_{1 p u}(s)=\frac{X_{f \ell}}{X_{0 \ell u}}=\frac{X+z_{e v} \theta_{y}+y_{\ell} \theta_{z}}{X_{0 \ell u}}
$$

ここで， $z_{e v}$ と $y_{\ell}$ はそれぞれ重心から評価位置までの高さ方向と横方向までの距離を表す．なお，上下のガイド装 置には，かごの昇降速度に応じた時間差 $\mathrm{L}$ 秒で同一の強制変位が入力される. この時間遅れは周波数領域では, ラプラス 演算子 $\mathrm{s}$ を用いて $e^{-L s}$ で表現できる. 左右に取り付けられた上下のそれぞれのガイド装置には, 乗りかごの昇降速度に起 因した時間差で, 同一のプロファイルをもつレールの不整が入力される.このため, 左下側のガイドが受ける強制変位から 左床前方の床応答変位までの伝達関数を $G_{1 p d}(s)$ と寸れば, レールの不整から床応答変位までの伝達関数は, 図 6 となる. すなわち, 上昇運転では, 先に上側のガイド装置にレールの不整 $X_{0}$ が入力されるので, 時間差を表す $e^{-L s}$ (塗りつぶした 部分) は $G_{1 p d}(s)$ で示寸下側ガイド装置から床応答変位までの伝達特性に結合され, これを $G_{1 p u}(s)$ と足し合わせたものが, レールから床への伝達特性となる. 下降の運転では, レールの不整を先に受けるのは, 下側のガイド装置であるため, それ ぞれ $e^{-L s}$ は， $G_{1 p u}(s)$ に接続される. このブロック図を用いて，レールの外乱に対する床応答を計算する.

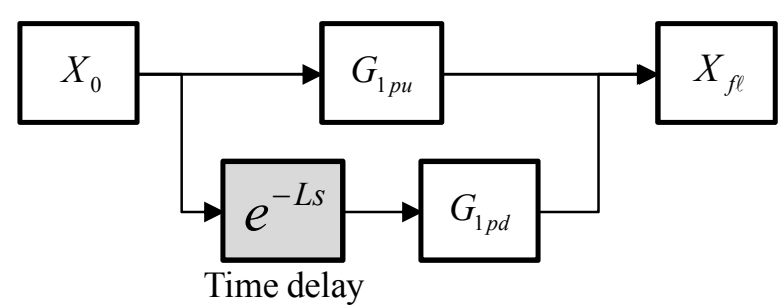

(a) Up

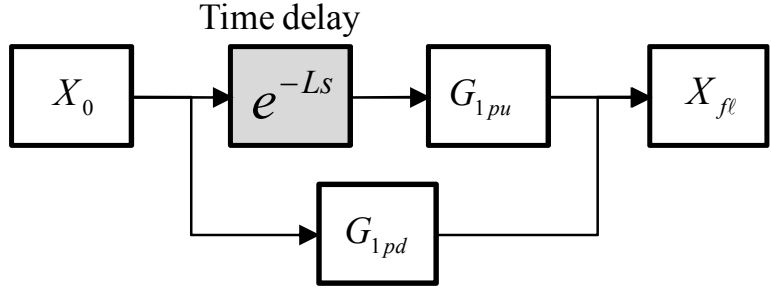

(b) Down

Fig.6 Block diagrams from rail disturbance to floor response 


\section{$2 \cdot 3$ 制御性を考慮したかごの構造変更}

エレベータの乗り心地向上に必要なのは, 乗客の立つ床面の振動低減である. 著者らは, 前報にてレールからかごへの伝 達特性に着目し，上側よりも下側レール不整から床面へのゲインが大きいことを示し，制振用のアクチュエータを下側に設 置した(4).これに対して，レールの外乱入力により励起される複数の振動モードが床位置で同じ方向，望ましくは両者の位 相が 0 となるように構造を変更すれば，後述の振動制御における制御性，すなわち制振性能の向上が期待できる. 図 7 に XZ 平面における並進と回転をそれぞれ主とする 2 つ振動モードが，理想的に床面で位相 $0^{\circ}$ の場合と $180^{\circ}$ の場合の概 念図を示寸. 本図は，アクチュエータ(口)をかごの下部に設けて加振した場合のかごの動きを表している. 左側の(i)と(ii)は

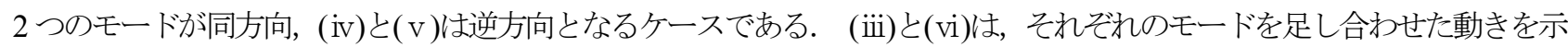
している. (i)の並進モードを抑制するには，アクチュエータで右側にかごに制御力を与える必要がある．この制御力では， (ii)の回転モードも同様に抑制できる.一方，(iv)の並進モードを抑制する場合，(i)と同様にアクチュエータで右側にかご に制御力を与える．この制御力では，(v)の回転モードを抑制する方向ではなく，かごの回転を増大させる側となる．この ように，アクチュエータを下側の夕に配置して，複数の振動モードが同方向に動くように構造変更する.

次に, この構造変更を行なうにあたっての機械パラメータについて述べる. エレベータの動的特性を決定する設計パラメ 一タは, かごの質量, 慣性と重心位置, ガイド部の岡性, 防振ゴムのばね定数や各種ダンパなどの減衰がある. 質量, 慣性, 重心は，かごの 3 次元形状や機器の配置によって決まるが，かごの意匠や省スペース性の観点より制約が大きいため，変更 幅は小さい，一方，ガイド装置は，乗りかごがロープによって懸架されているため，自動車や鉄道のように車体を支持する 機能は持たない，このため，ローラガイド装置は，乗客の偏荷重による変形と防振機能を満たす範囲で，剛性変更の自由度 が高い.

\section{$2 \cdot 4 \mathrm{TX}$ と RY モードに関する検討}

図 5 の XZ 平面内の振動について，TX と RY の 2 つのモードを対象とした構造変更を検討する. 変更パラメータは, (1) 上下に配置したガイド装置のそれぞれの等佃剛性，(2) 乗客によるかご質量および重心位置とする. 通常（以下，初期構造 と記す）は，上下のガイド装置の岡性は同じ值としているが，ここでは初期構造に対する上下のガイド装置の岡性をそれぞ れ $\alpha_{\mathrm{u}}$ 倍と $\alpha_{\mathrm{d}}$ 倍とする. そして, 表 1 に示寸乗りかごを対象に, これらの岡性比率 $\alpha=\alpha_{\mathrm{v}} / \alpha_{\mathrm{d}}$ を変化させて, 左右のレール 外乱変位を同一とした場合の，TX と RY モードの床位置における位相差を求める. なお，減衰パラメータは著者らが実機 のエレベータを対象に実稼働モード解析により求めたモード減衰比(TX : $3.2 \%, \mathrm{RY}: 2.67 \%)$ をもとに, 減衰行列を質量行 列と岡性行列にそれぞれ 0.645 と $1.766 \times 10^{-3}$ をかけて与えている(9).

図 8 (a)に下側のガイド剛性について初期值に対する倍率 $\alpha_{\mathrm{d}}$ を $1,2,3$ と変更した場合の, 剛性比率 $\alpha$ と位相差の 関係を示す．これによれば， $\alpha$ にって位相差が大きく変化しており， $\alpha_{d}$ による影響は小さいことがわかる．次 に，乗客の積載を想定して，かご質量と重心位置を変化させた場合の計算結果を図 8(b)に示す. 実際の乗りかごは, 乗りか ごの下側に床, 非常止め装置などの重量物が存在するため, かごの重心は表 1 に示すように乗りかごの下方になる. 乗客の 積載によって積載前に比べて $0.2 \mathrm{~m}$ だけかごの重心が下がる場合，位相変化は $\alpha$ が小い側にシフトすることがわかる．な お，図示しないが，運転方向の違いや速度の違いは，これらの特性変化に比べて十分小さいことを確認した. 以上より，重 心位置の変動による位相差変化も考慮して， $\alpha$ は 0.2 0.5(下側のガイド岡性を上側の 2 5 倍)の範囲が最適と考えられる.

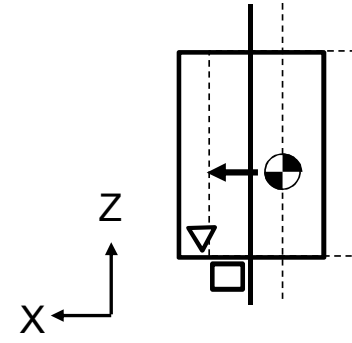

(i) Trans.

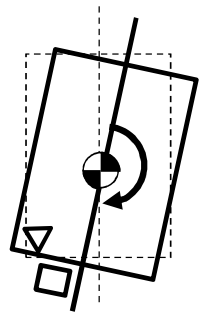

(ii ) Rot.

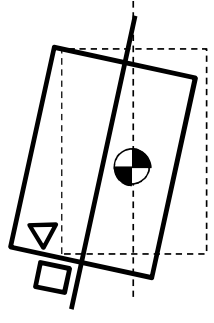

(iii) Trans.+Rot.

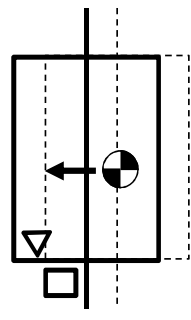

(iv) Trans.

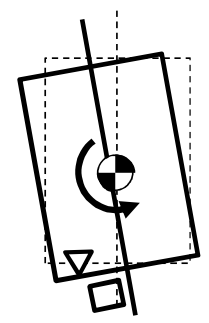

( v ) Rot.

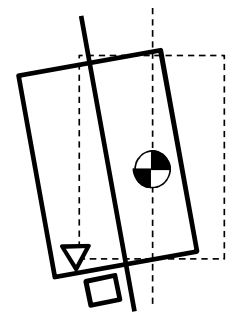

(vi) Trans.+Rot.

(a) Same direction

Fig.7 Vibration modes

(b) Opposite direction 
Table 1 Car dynamics parameters

\begin{tabular}{|c|c|c|c|}
\hline No. & Specification & Symbol & Value \\
\hline 1 & Car mass & $M$ & $2300 \mathrm{~kg}$ \\
\hline 2 & Moment of inertia of car (Rotational Y) & $I_{y}$ & $5.83 \times 10^{3} \mathrm{~kg} \cdot \mathrm{m}^{2}$ \\
\hline 3 & Moment of inertia of car (Rotational Z) & $I_{z}$ & $2.12 \times 10^{3} \mathrm{~kg} \cdot \mathrm{m}^{2}$ \\
\hline 4 & Equivalent mass of roller guide & $m_{\ell u}, m_{r u}, m_{\ell d}, m_{r d}$ & $5 \mathrm{~kg}$ \\
\hline 5 & Length from upper roller to center of gravity & $z_{u}$ & $2.79 \mathrm{~m}$ \\
\hline 6 & Length from lower roller to center of gravity & $z_{d}$ & $2.30 \mathrm{~m}$ \\
\hline 7 & Length from floor to center of gravity & $z_{e v}$ & $1.05 \mathrm{~m}$ \\
\hline 8 & Length from right roller to center of gravity & $y_{\ell}$ & $1.075 \mathrm{~m}$ \\
\hline 9 & Length from left roller to center of gravity & $y_{R}$ & $1.075 \mathrm{~m}$ \\
\hline 10 & Stiffness of spring & $k_{g \ell u}, k_{g r u}, k_{g \ell d}, k_{g r d}$ & $110 \times 10^{3} \mathrm{~N} / \mathrm{m}$ \\
\hline 11 & Stiffness of roller & $k_{\ell r u}, k_{r r u}, k_{\ell r d}, k_{r r d}$ & $1732 \times 10^{3} \mathrm{~N} / \mathrm{m}$ \\
\hline 12 & Damping coefficient (Mass proportional) & - & 0.645 \\
\hline 13 & Damping coefficient (Stiffness proportional) & - & $1.766 \times 10^{-3}$ \\
\hline 14 & Car velocity & $\mathrm{V}$ & $6 \mathrm{~m} / \mathrm{s}$ \\
\hline
\end{tabular}

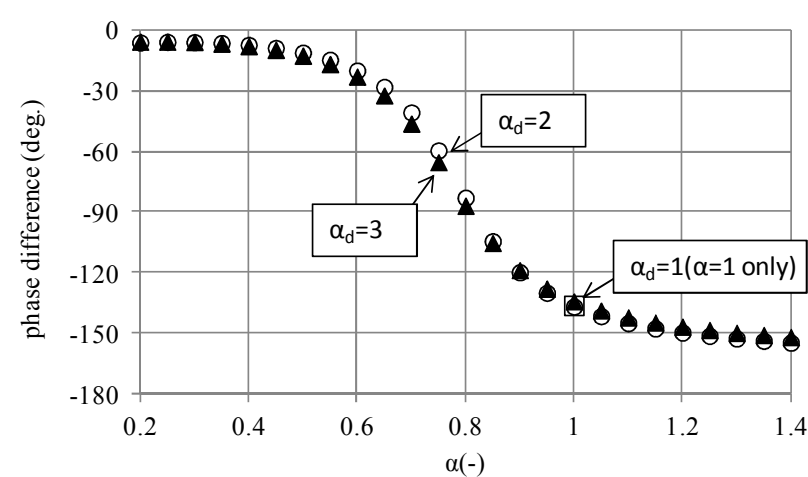

(a) influence of $\alpha_{\mathrm{d}}$

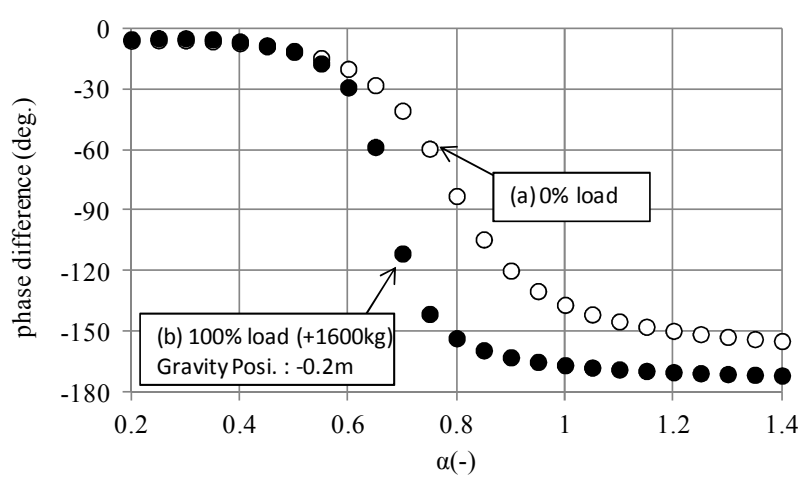

(b) Influence of car mass

Fig.8 Phase difference between TX and RY mode by simulation

\section{$2 \cdot 5$ その他の方向に関する考察}

TX と RZモードについては，Y 方向(かごの横方向)の重心がほぼ中心にあるため，床の右前前方と左奥後方では，RZモ 一ドが励起された場合にそれぞれの位置のX方向の振動方向が逆になる. すなわち，TX とZモ一ドは，床面全ての位置 で同方向の応答にすることはできない，また，TXの RZは，どちらのモードがより顕在化するか壮，左右のレール不整の パターンによって変わる. このため, 高さ位置におけるレールの情報を, 既に著者らが提案した方法等によって求め ${ }^{(10)}$, レ 一ルの不整方向に応じて，TXを主に抑制する制御コントローラと， RZを主に抑制する制御コントローラを切り替える方 法により対処する.

また，TY と RXモードは，上下のガイド装置の岡性の絶対值はX方向とは異なるものの，上記の XZ 平面における $\mathrm{TX}$ とRYに関する検討と等価と考えることができる. 


\section{3. 制 御 設 計}

\section{3・1 Ho制御設計}

上記の機構設計に基づいて，図 5 に示寸乗りかごの機構モデルを用いて，TX と RY と RZ の振動低減に対する制御設計 を行なった. センサとアクチュエータの配置は, 図9に示すアクチュエータを下側のみ配置と, 上下配置の 2 パターンを検 討した. 前者の場合には, 加速度センサはかご枠フレームのかご床直下とローラ台に2 個取り付けており，後者の場合には 各ローラ台に取り付け，いずれもX方向の加速度を検出する. 図 10 に今回検討対象とするシステム構成を示す. (a) は初 期構造で下側にアクチュエータを設置, (b)は提案構造(位相差の縮小構造)で下側にアクチュエータを配置, (c)は初期構造で 上下にアクチュエータを設置した場合の3ケースである.

この制御対象を含めた一般化プラントを図 11 のように構成し，制御設計には，周波数整形が可能でロバス卜設計として 一般的な $\mathrm{H} \infty$ 制御設計を用いる. この設計では, 観測した加速度信号と制御量に対して, 周波数重みを設定し相反する乗り 心地と， ロバスト性の向上を図る. 外乱 $\omega$ はレール外乱 $\omega_{\mathrm{p}}$, 入力ノイズ $\mathrm{p}$, 加速度センサ出力に含まれる観測ノイズ $\mathrm{n}$ で ある. また，制御量 $\mathrm{z}$ は制振性能に関する制御量 $\mathrm{z}_{1}$ と，モデル化誤差に対するロバス卜性に関する制御量 $\mathrm{z}_{2}$ で構成する. 今回は, 外乱 $\omega$ から制御量 $\mathrm{z} へ の$ 伝達関数の $\mathrm{H} \infty$ ノルムを最小化するように設計する. 乗り心地は, 主に $4[\mathrm{~Hz}]$ 以下の低周 波数で人間の感度が高いため, $\mathrm{W}_{\mathrm{p}}$ にはこの周波数帯域を含む重みを設定し， $\mathrm{W}_{\mathrm{r}}$ をモデルの不確かさを表現する重みをとし て $\mathrm{W}_{\mathrm{p}}$ 以上の周波数帯域に設定した. 図中の $\mathrm{F}$ はノイズ $\mathrm{n}$ を除去するフィルタである. 乗り心地性能とロバスト性は, 相反 関係にあり，試行錯誤によりこれらの重みを決定した. $\mathrm{W}_{\mathrm{p}}, \mathrm{W}_{\mathrm{r}}, \mathrm{W}_{\mathrm{f}}$ の各状態量をそれぞれ， $\mathrm{X}_{\mathrm{wp}}, \mathrm{X}_{\mathrm{wr}}, \mathrm{X}_{\mathrm{f}}$ として, $\mathrm{X}_{\mathrm{wp}}$ にい ての状態方程式と出力方程式をそれぞれ， $\dot{\mathbf{x}}_{\mathrm{wp}}=\mathbf{A}_{\mathrm{wp}} \mathbf{x}_{\mathrm{wp}}+\mathbf{B}_{\mathrm{wp}} \mathbf{z}_{\mathrm{p}}, \mathbf{z}_{1}=\mathbf{C}_{\mathrm{wp}} \mathbf{x}_{\mathrm{wp}}+\mathbf{D}_{\mathrm{wp}} \mathbf{z}_{\mathrm{p}}$ とすれば，一般化プラントの 状態方程式は(4)〜(6)式となる.

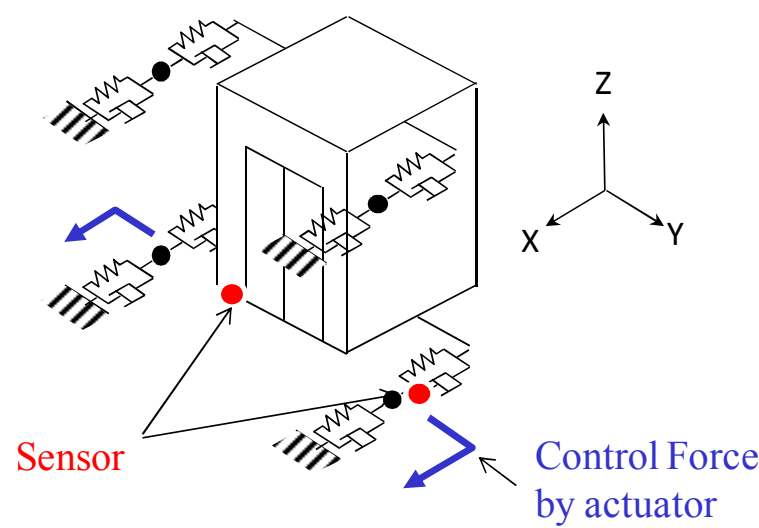

(a) Lower side only

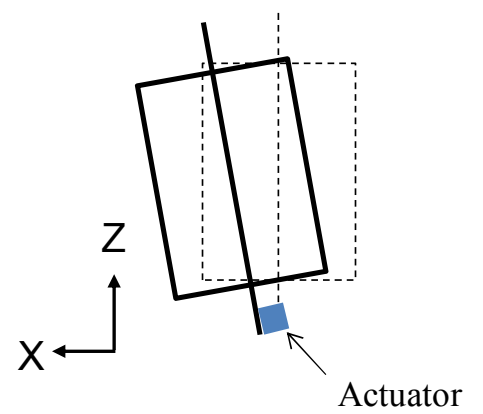

(a) CaseA

Fig. 9 Sensor and actuator arrangement

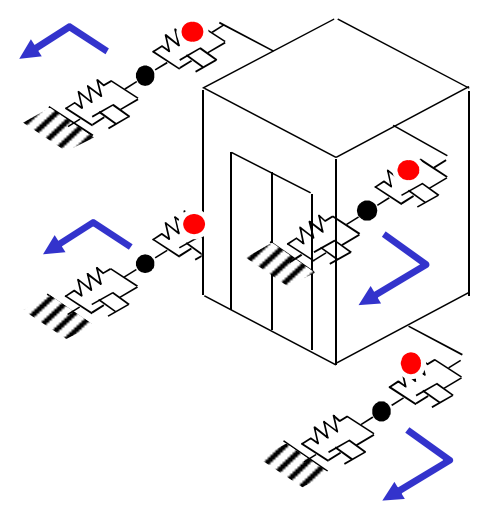

(b) Upper and lower side

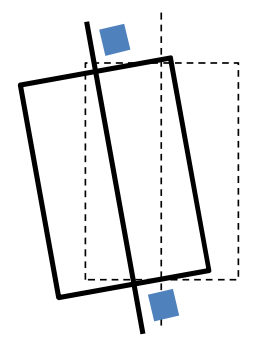

(c) CaseC

Fig.10 Analytical case 


$$
\begin{aligned}
& {\left[\begin{array}{c}
\dot{\mathbf{x}}_{\mathrm{p}} \\
\dot{\mathbf{x}}_{\mathrm{wp}} \\
\dot{\mathbf{x}}_{\mathrm{wr}} \\
\dot{\mathbf{x}}_{\mathrm{f}}
\end{array}\right]=\left[\begin{array}{cccc}
\mathbf{A}_{\mathrm{p}} & \mathbf{0} & \mathbf{0} & \mathbf{0} \\
\mathbf{B}_{\mathrm{wp}} & \mathbf{A}_{\mathrm{wp}} & \mathbf{0} & \mathbf{0} \\
\mathbf{0} & \mathbf{0} & \mathbf{A}_{\mathrm{wr}} & \mathbf{0} \\
\mathbf{B}_{\mathrm{f}} \mathbf{C}_{\mathrm{p} 2} & \mathbf{0} & \mathbf{0} & \mathbf{A}_{\mathrm{f}}
\end{array}\right]\left[\begin{array}{c}
\mathbf{x}_{\mathrm{p}} \\
\mathbf{x}_{\mathrm{wp}} \\
\mathbf{x}_{\mathrm{wr}} \\
\mathbf{x}_{\mathrm{f}}
\end{array}\right]+\left[\begin{array}{ccc}
\mathbf{B}_{\mathrm{p} 1} & \mathbf{B}_{\mathrm{p} 2} & \mathbf{0} \\
\mathbf{B}_{\mathrm{wp}} \mathbf{D}_{\mathrm{p} 11} & \mathbf{B}_{\mathrm{wp}} \mathbf{D}_{\mathrm{p} 12} & \mathbf{0} \\
\mathbf{0} & \mathbf{0} & \mathbf{0} \\
\mathbf{B}_{\mathrm{f}} \mathbf{D}_{\mathrm{p} 21} & \mathbf{B}_{\mathrm{f}} \mathbf{D}_{\mathrm{p} 22} & \mathbf{B}_{\mathrm{f}}
\end{array}\right]\left[\begin{array}{c}
\boldsymbol{\omega}_{\mathrm{r}} \\
\mathbf{p} \\
\mathbf{n}
\end{array}\right]+\left[\begin{array}{c}
\mathbf{B}_{\mathrm{p} 2} \\
\mathbf{B}_{\mathrm{wp}} \mathbf{D}_{\mathrm{p} 12} \\
\mathbf{B}_{\mathrm{wr}} \\
\mathbf{B}_{\mathrm{f}} \mathbf{D}_{\mathrm{p} 22}
\end{array}\right] \mathbf{u}} \\
& {\left[\begin{array}{l}
\mathbf{z}_{1} \\
\mathbf{z}_{2}
\end{array}\right]=\left[\begin{array}{cccc}
\mathbf{D}_{\mathrm{wp}} \mathbf{C}_{\mathrm{p} 1} & \mathbf{C}_{\mathrm{wp}} & \mathbf{0} & \mathbf{0} \\
\mathbf{0} & \mathbf{0} & \mathbf{C}_{\mathrm{wr}} & \mathbf{0}
\end{array}\right]\left[\begin{array}{c}
\mathbf{x}_{\mathrm{p}} \\
\mathbf{x}_{\mathrm{wp}} \\
\mathbf{x}_{\mathrm{wr}} \\
\mathbf{x}_{\mathrm{f}}
\end{array}\right]+\left[\begin{array}{ccc}
\mathbf{D}_{\mathrm{wp}} \mathbf{D}_{\mathrm{p} 11} & \mathbf{D}_{\mathrm{wp}} \mathbf{D}_{\mathrm{p} 12} & \mathbf{0} \\
\mathbf{0} & \mathbf{0} & \mathbf{0}
\end{array}\right]\left[\begin{array}{c}
\omega_{\mathbf{r}} \\
\mathbf{p} \\
\mathbf{n}
\end{array}\right]+\left[\begin{array}{c}
\mathbf{D}_{\mathrm{wp}} \mathbf{D}_{\mathrm{p} 12} \\
\mathbf{D}_{\mathrm{wr}}
\end{array}\right] \mathbf{u}}
\end{aligned}
$$

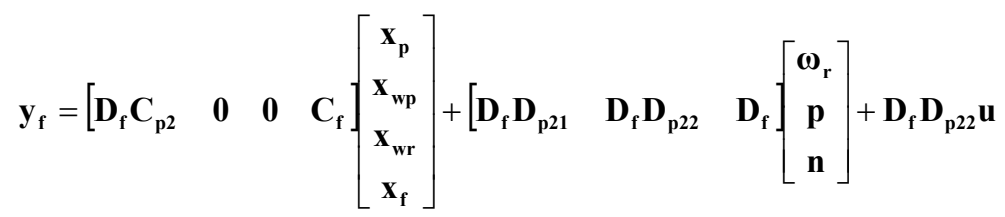

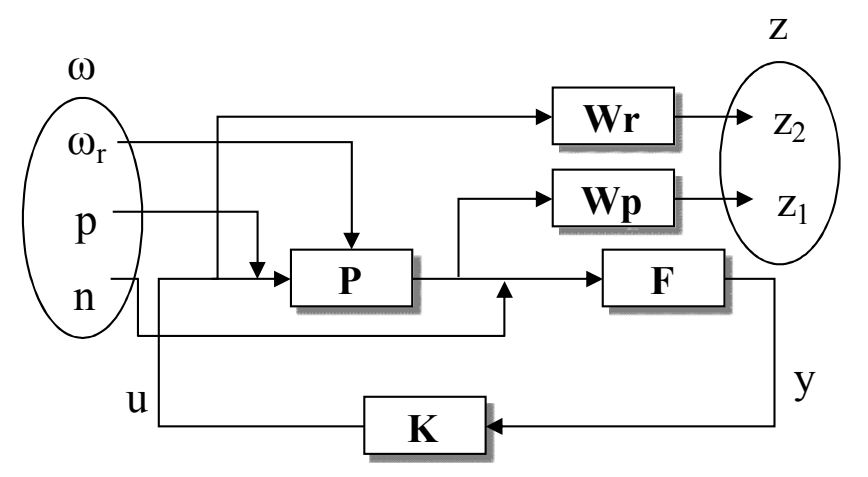

Fig. 11 Block diagram of generalized plant

\section{$3 \cdot 2$ 解析結果}

表 2 に図 10 のモデルを用いて，初期構造と上下のガイド装置のパラメータ $\alpha_{\mathrm{d}}=2$ で $\alpha=0.2$ を選定した構造の 2 ついい ての位相差の計算結果を示す.レールからの外乱に対する2つの振動モードの位相差は, 初期と提案構造でそれぞれ1060，

6 で構造変更により位相差を縮小できている.

次に，図 12 に左上側のガイド装置に入力されるレール強制変位から，床位置加速度までの閉ループ系の伝達特性，図 13 に左下側のガイド装置に入力されるレール強制変位からの同様の伝達特性を示す。この図より，上側のガイド装置からの入 力に対し, 制御無しのパッシブの状態において, 初期構造に比べて提案構造の方が, 全てのモ一ドについて振動伝達ゲイン が低下していることがわかる．逆に，下側ガイド装置からの入力に対しては，3次モード(RYモード)のゲインが増大して いる. この構造に対して制御を行なうと，(a)に比べて(b)と(c)のコントローラで伝達ゲインを大きく低減できており，特に 上側からの入力に対して，(b)よりも(c)の方が低減効果が大きいことがわかる.

Table2 Phase calculation results (degree)

\begin{tabular}{c|c|c}
\hline Mode & Initial & Proposed \\
\hline \hline TX mode & -53 & -56 \\
\hline RY mode & 53 & -50 \\
\hline Difference & 106 & 6 \\
\hline
\end{tabular}



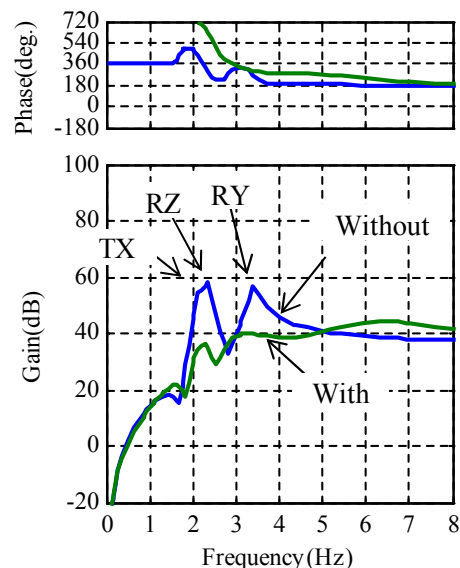

(a) Case A
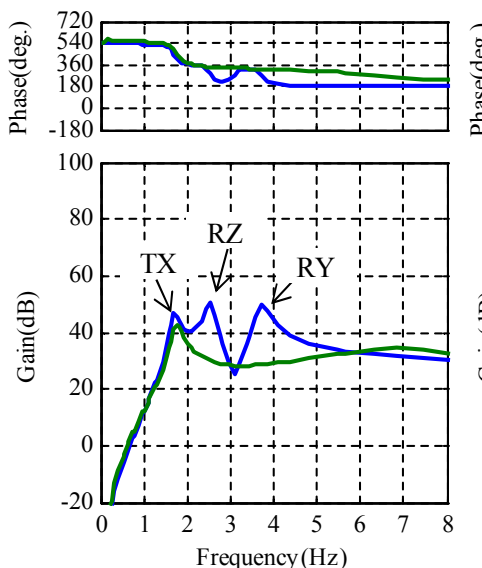

(b) Case B
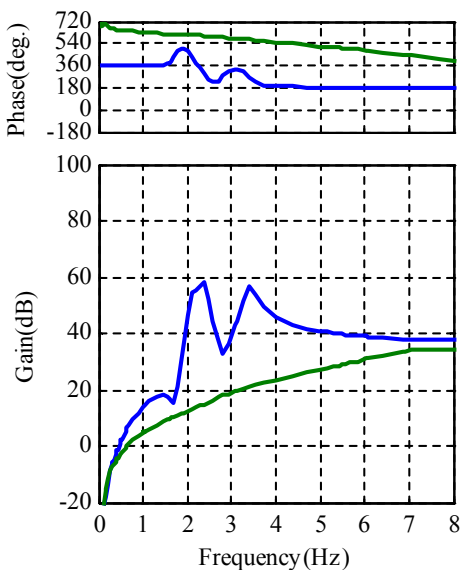

(c) Case C

Fig.12 Closed loop transfer functions (From upper guide)
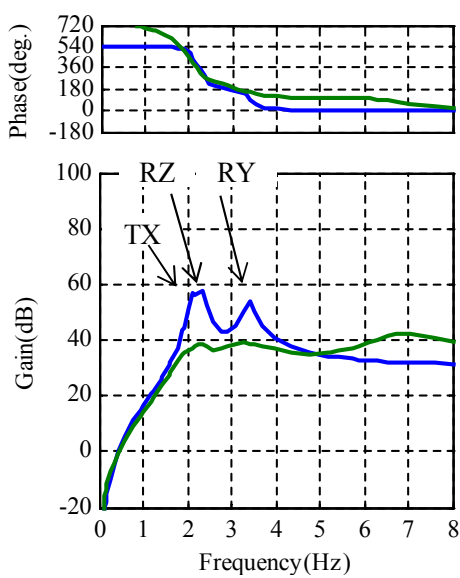

(a) Case A

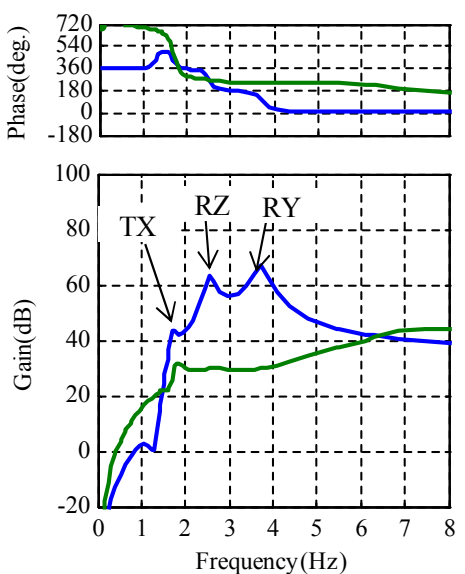

(b) Case B

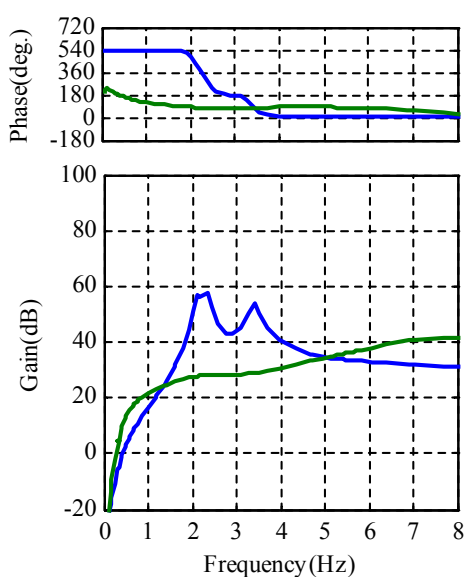

(c) Case C

Fig.13 Closed loop transfer functions (From lower guide)

さらに，構造変更の効果を検証するため，左右のレールが同一量/方向で，上下で時間差(1.2[s])のあるステップ入力を 与えて, 応答計算を行なった(図 14). 最上段は入力変位を表し(最大変位で基準化), これより下段の 4 つの図は, 図 10 の Case A〜Cに対応した制御を行なった際の床位置の応答加速度を示している. 応答加速度は, 乗り心地評価である, 約 $2[\mathrm{~Hz}]$ にピーク周波数をもつISO フィルタタ(8)をかた波形である.これらの図より，Case A では制御無しに比べて約 $45 \%$ の振動 低減効果が見られるが，ステップ入力後に残留振動が認められる. これに対し，アクチュエータの制御力を増して制振効果 を高めるように, 周波数重みを変更して制御設計を行なったが，コントローラの極が不安定となるだけで制御性能の改善は 見られなかった. 一方, Case B の提案構造では, 約 64\%の振動低減効果が見られ, 残留振動もほほ除去できている. なお, Case C の逆相構造で上下にアクチュエータを配置する構造でも同様に振動抑制効果は大きい.

次に，レールの外乱条件を変えた場合の，Case A〜Cでの応答計算結果を図 15 に示寸. Case A に比べてCase B と Cの 制振効果が高いことがわかる．なお，左側入力での Case B とC の差はほとんどないが，左右が逆相の入力を受ける場合に は, Case B よりも制御䡛数の多いCase C の方が制振効果が高くなっている.これは, 閉ループ系の伝達特性が示寸ように, 上側からの入力に対して，(b)よりも(c)の方が，RZモードの振動低減効果が大きいことに起因している. 

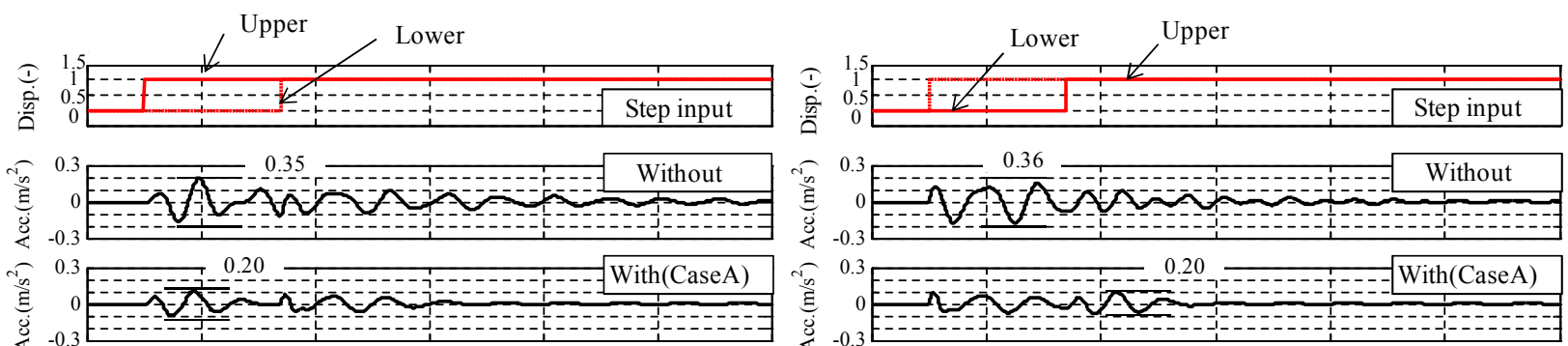

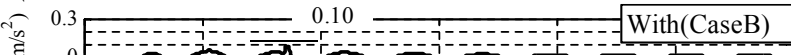

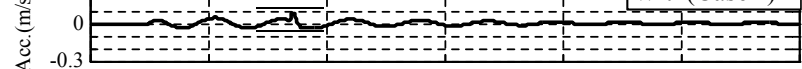

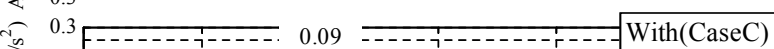
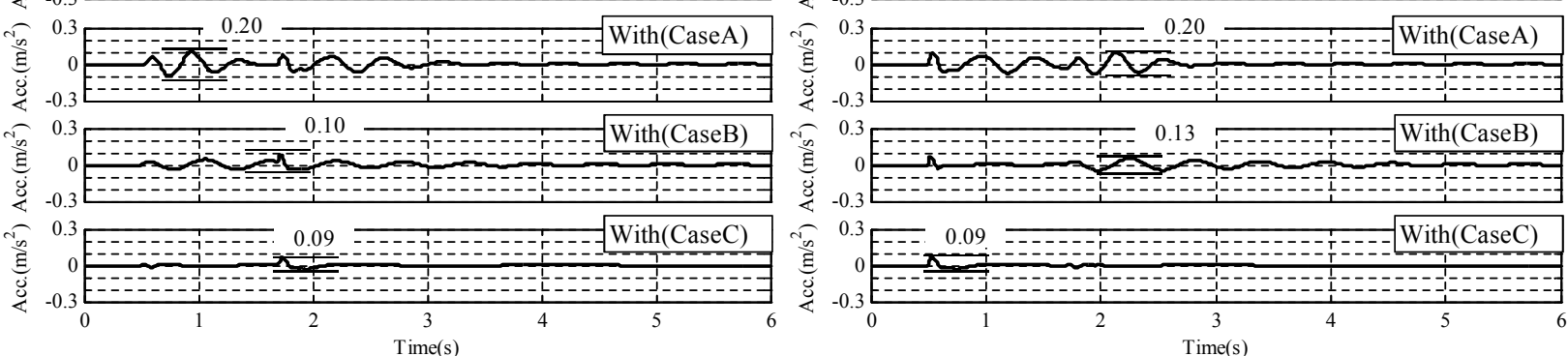

(a) UP

(b) Down

Fig.14 Simulation results by Left and right inputs (Same direction)
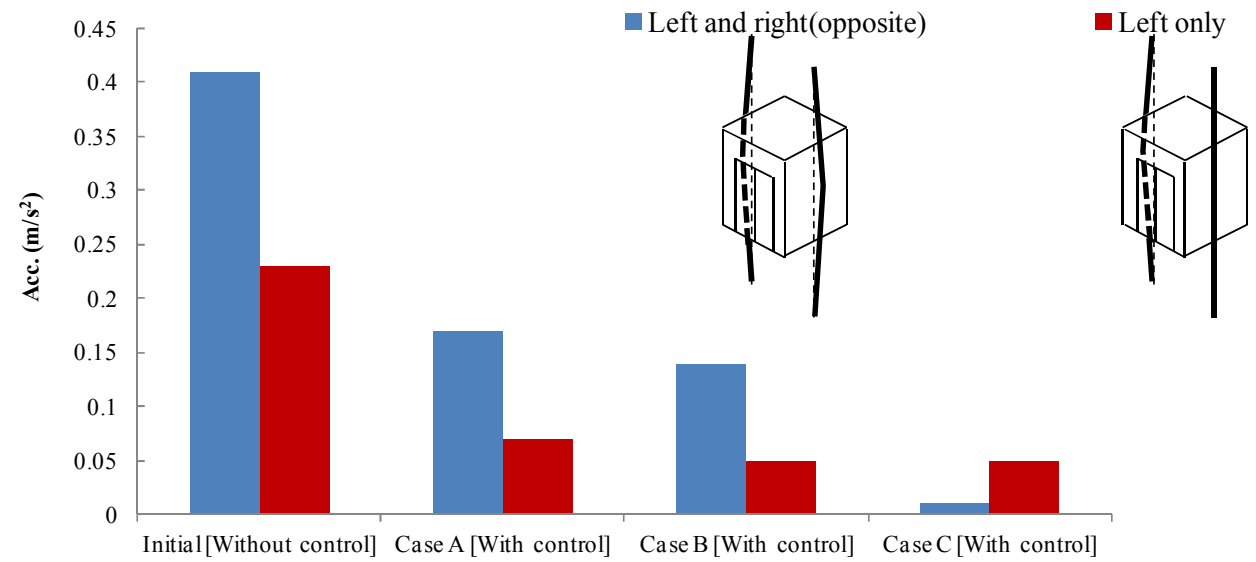

Fig.15 Simulation results

\section{4. 検 証 実 験}

\section{$4 \cdot 1$ 実験方法}

図 16 に示すように，エレベータの走行状態を模擬する等価試験機を用いて，検証実験を行なった．この装置には，ガイ ドローラに接する回転円盤が上下に 4 か所設置されており，それぞれの円盤に接続した油圧加振機で図中の Y 方向に強制 変位を与えることができる．なお，これまでの解析検討は，TX と RY モードについての検討であるが，位相差を縮小して 制御性能を向上寸る設計手法はTY と RXでも同様と考え，Y方向の加振でも，制振効果の評価が可能と判断した.

乗りかごは，上部のベースとロッドを介して連結されており，上部から吊られた状態になっている. 入力波は，これらの 4 つの円盤に対して，任意の波形を独立に与えることができる. 乗りかごの加速度センサは，かごのフレーム部分に制御用 の加速度センサを設置して, 床と天井の応答評価用の加速度センサを設置している. 検証にあたり, 油圧加振機で加振試験 を行ない, 乗りかごの固有振動数の情報を得た. その結果, 1 次と 2 次の固有振動数はそれぞれ, 初期構造で 2.1[Hz] (並進),

$2.4[\mathrm{~Hz}]($ 回転), 提案構造で $2.8[\mathrm{~Hz}$ (並進), $4.3[\mathrm{~Hz}]$ (回転)であった.

次に，制振効果の検証を行なうため，走行模擬試験では，正弦 3 波を右側上下の円盤に対してY 方向に油圧加振機で強 制変位を与えた. この加振周波数は, 乗りかごの固有振動数に一致する周波数として, 上下の円盤にはそれぞれの走行速度 に応じた時間差をつけて強制変位加振を行なった. 乗りかごの構造変更は, 段差通過時の高次の振動を抑えることも考慮し 
て，今回は下側のガイド装置を初期の 2 倍，上側は初期構造と同一とした(ガイド剛性比 $\alpha=0.5$ に相当). これらの構造につ いて，加振試験を行なって制振効果を比較する.

\section{$4 \cdot 2$ アクティブローラガイド装置}

制振制御を行なうアクティブガイド装置の概要を図 17 に示寸. 本図(a)は, 乗りかごのX方向から見た正面図を示してお り，Y方向の制振用には, アクティブガイド装置を赤枠で囲んだ左下のみに取り付ける. かごのフレームに設けた左右の口 一ラは，図4 に示すようにX軸方向において同一線上にあるため，一つのアクチュエータで制御力を与えればその反力が フレームを介してもう一方のガイドレバーに作用する. また, 左右のレバーがローカルに運動するモードはないため, 左右 のガイド装置のうち右側のみのレバーを駆動制御する方法としている. ローラガイド装置は, アクチュエータを持たないパ ッシブ型の場合には(b)に示す構成であるが，アクティブ型では(c)に示すようにパッシブ型に塗りつぶした駆動部分を追加 している. すなわち，レバーの先端にばねを設置してこれをサドルと連結し，サドルに回転式のモータとボールねじを連結 してY方向に駆動制御することができる.

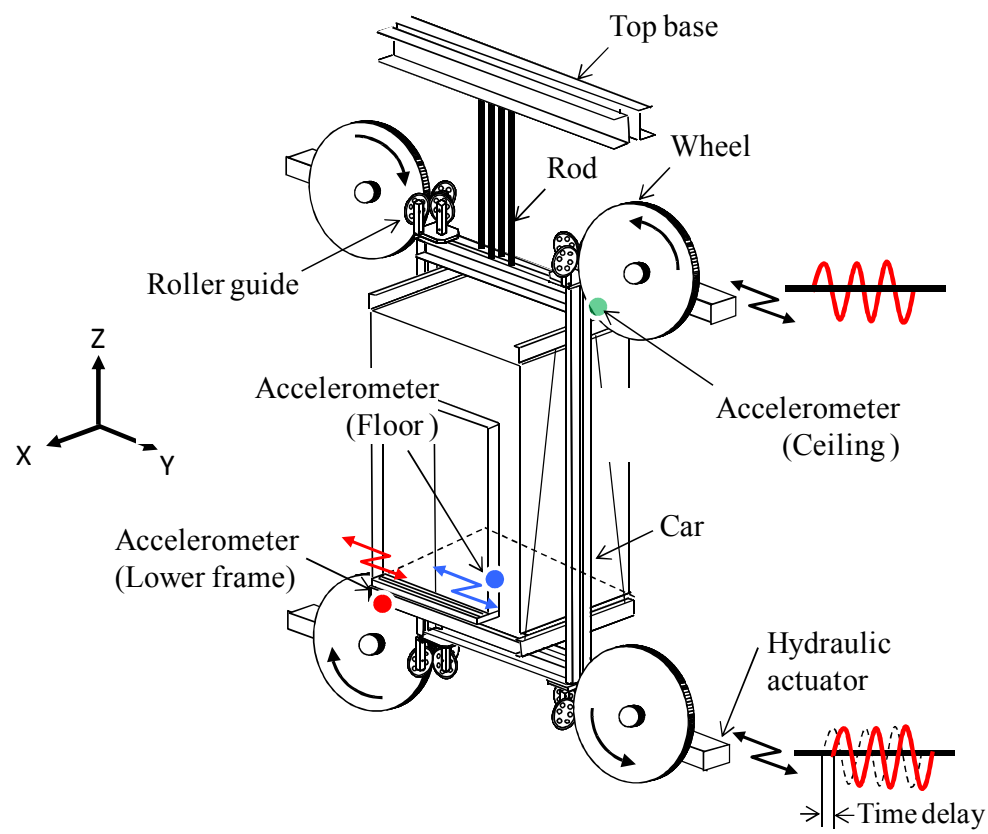

Fig. 16 Experimental setup

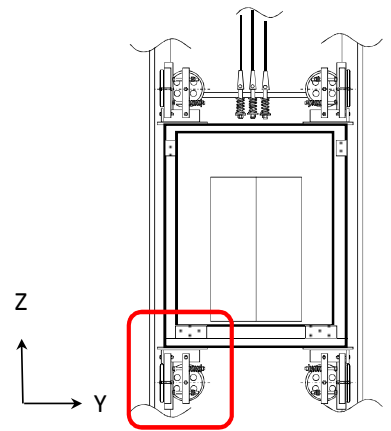

(a) Overview of elevator car

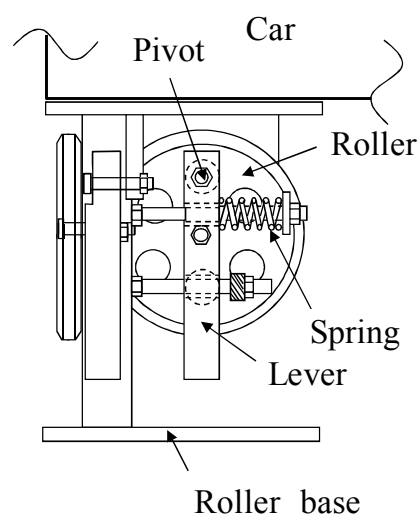

(b) Passive roller guide

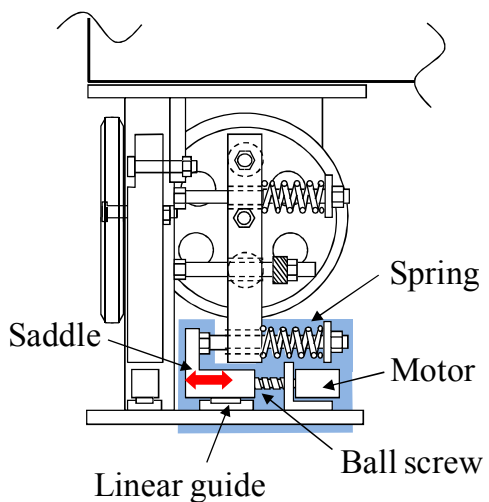

(c) Active roller guide

Fig. 17 Diagram of an active roller guide 


\section{$4 \cdot 3$ 実験結果}

(1) 構造変更による位相の変化

構造変更による位相の変化を調べるため, 回転モードの位相が床面よりも見やすい天井位置における加速度を用いて評価 を行なう. 図 18 に入力変位と天井の応答加速度を示寸. 入力波形は，それぞれ 1 次と 2 次の共振 3 波を上下のガイド装置 に入力し,この入力波形と応答波形から位相差を計算した. 天井加速度から床位置における各モードの位相を推定するため, 2 次の回転モードについては天井の加速度波形の位相を $180^{\circ}$ 反転する. 表 3 に入力变位に対する位相を示寸．初期構造で は 1 次と 2 次モードの位相差が $79^{\circ}$ に対し，提案構造では $23^{\circ}$ に縮小されている.

\section{(2) 制振効果の検証}

次に，制振性能の評価試験結果について，図 19 に床位置の加速度波形を示寸. 左側には並進 1 次モードの共振応答，右 側に回転 2 次モードの共振応答について, それぞれ初期構造による制御有無と提案構造の制御有の比較を示寸. 表4 はこれ らの両振幅の最大值をまとめて示し，（）内には制御無しとの比較を\%で表示している．提案構造では，制御無しに比心゙ て振動を $1 / 2$ 以下にできている. さらに，制御有に着目寸れば，初期構造に比べて提案構造の方が， 1 次モード， 2 次モ一 ドともに低減効果が大きく，それぞれの改善量は，低減率\%の差を取り 55，22 ポイントとなっている.
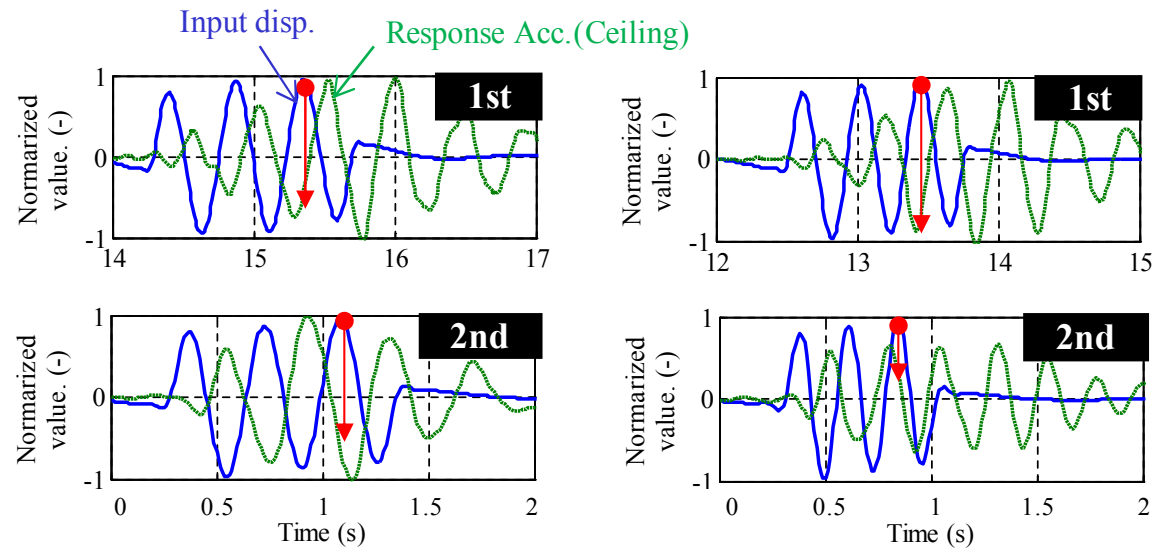

(a) Initial

(b) Proposed

Fig. 18 Comparison of Input disp. and ceiling acceleration

Table3 Phase of 1st and 2nd modes (degree)

\begin{tabular}{c|c|c|c}
\hline Type & 1st mode & 2nd mode & difference \\
\hline \hline Initial & 138 & 59 & 79 \\
\hline Proposed & 133 & 156 & 23 \\
\hline
\end{tabular}



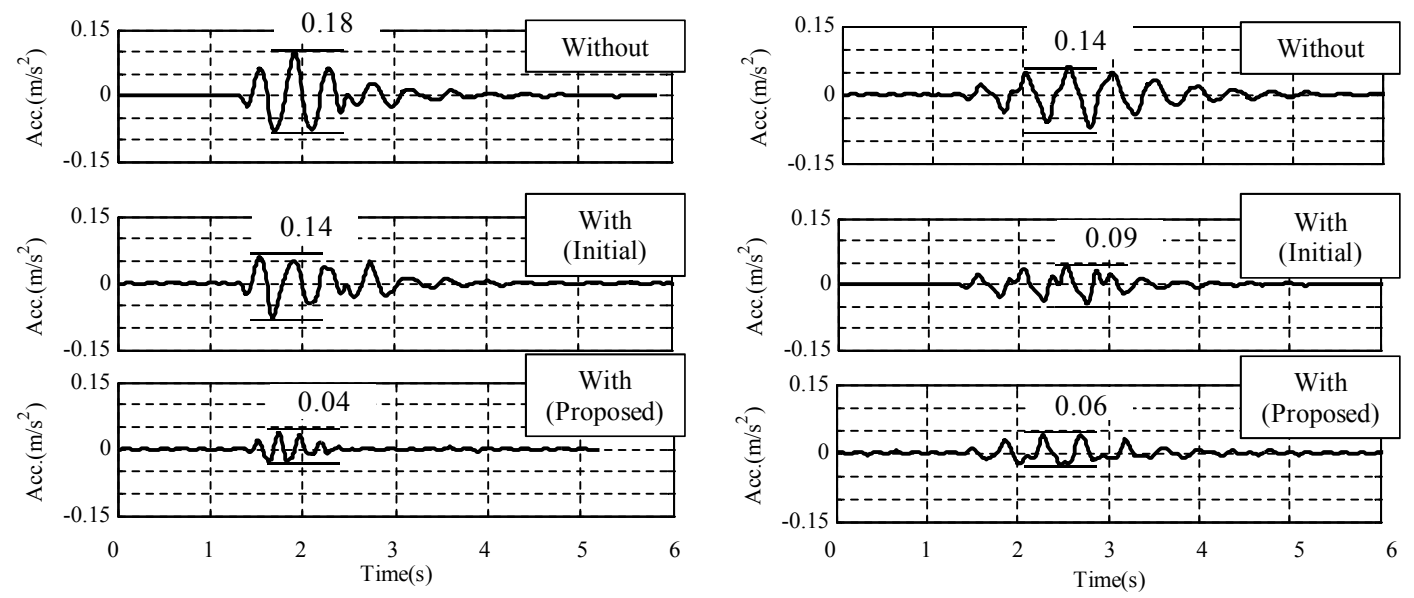

(a) 1st mode

(b) 2nd mode

Fig. 19 Experimental results

Table4 Experimental results $\left(\mathrm{m} / \mathrm{s}^{2}\right)$

\begin{tabular}{c|c|c|c}
\hline Mode & Initial [Without control] & Initial [With control] & Proposed [With control] \\
\hline \hline TX & 0.18 & $\begin{array}{c}0.14 \\
(-23 \%)\end{array}$ & $\begin{array}{c}0.04 \\
(-78 \%)\end{array}$ \\
\hline RY & 0.14 & $\begin{array}{c}0.09 \\
(-36 \%)\end{array}$ & $\begin{array}{c}0.06 \\
(-58 \%)\end{array}$ \\
\hline
\end{tabular}

\section{5. 結}

エレベータのアクティブ制御による横振動低減を目的として，そのかご構造および制御設計方法を検討し，以下の結論 を得た。

(1) 上下のガイド装置が時間差を有するレールからの強制変位から床加速度への伝達関数について，ガイド装置の上下の剛 性をパラメータに，並進と回転モードの位相特性を明らかにした。 その結果，下側のガイド装置の剛性を上側に対して約 2 倍〜5倍にすることで，床位置でのこれらのモードの位相差を縮小できることがわかった.

(2) 並進と回転モードの位相を初期構造の $106^{\circ}$ に対して $6^{\circ}$ に縮小した構造について, 2 つアクチュエータを用いた場合 のH卌御コントローラを設計し，初期構造でのアクティブ制振による低減率-45\%に対して，提案構造で最大-64\%に制振 性能が高まることを解析により明らかにした.

(3) 上記の構造について，地上での走行等価試験を行ない，下側のガイド装置を 2 倍にした構造で, 初期構造の位相差 $79^{\circ}$ に対して $23^{\circ}$ に縮小し，床位置の振動抑制効果を最大で約 55 ポイント改善できることを実験的に確認した.

\section{文献}

(1) 古市 崇, 福島 直人, 萩原 一郎, “ランダム路面入力シミュレーションを用いた油圧アクティブサスペンションの 最適設計手法”，日本機械学会論文集 C 編，Vol. 71, No. 701 (2005), pp. 152-156.

(2) 山下勝司, ロバスト制御理論に基づく自動車用アクティブサスペンションの制御系設計, 博士論文(東京大学)(1996).

(3) 鈴木卓馬, 高橋正樹, “路面入力に対する車両の平面運動を考慮した自動車用アクティブサスペンションの制御系 設計”，日本機械学会論文集 C 編，Vol. 76, No. 772 (2010), pp. 3558-3566.

（4）野口 直昭, 荒川 淳, 宮田 弘市, 吉村 卓也, 新 誠一, “高速エレベータ用乗りかごのアクティブ振動制御に関す る研究”, 日本機械学会論文集 C 編, Vol. 75, No. 754 (2009), pp. 1618-1625. 
(5) 小野 京右, 武川 浩士, 山浦 弘, “摇動アーム機構の固有振動モードの同相化設計によるヘッド位置決め機構の高 帯城化”，日本機械学会論文集 C 編，Vol. 64, No. 620 (1998), pp. 1347-1355.

(6) 上田 淳, 吉川 恒夫, “高速高精度駆動のためのタスクの優先順位を考慮した機械系の同相化設計法”, 日本機械学 会論文集 C 編，Vol. 68, No. 665 (2002), pp. 60-67.

(7) 熱海 武憲, 有坂 寿洋, 清水 利彦, 山口 高司, “八ードディスク装置の機構共振制振サーボ技術”, 日本機械学会 論文集 C 編，Vol. 68, No. 675 (2002), pp. 3298-3305.

(8) ISO18738, INTERNATIONAL STANDARD LIFTS(elevators)-Measurement of Lift ride quality (2003).

（9）小林 樹幸, 吉村 卓也, 野口 直昭, 大宮 昭弘, “実稼動モード解析を用いたエレベータ乗りかごの動特性推定”, 日本機械学会論文集 C 編，Vol. 74, No. 739 (2008), pp. 548-553.

(10) 野口 直昭, 荒川 淳, 吉村 卓也, 関谷 裕二, “エレベータの実稼動時の加速度データを用いたレール曲がりの同 定法”，日本機械学会論文集 C 編，Vol. 78, No. 786 (2012), pp. 431-445. 